\title{
THE PHILOSOPHY OF THE MODERN AGE: THE ISSUE OF THE SOURCE OF MEANINGFUL PRESENCE
}

\begin{abstract}
A brief analysis of the philosophy of the Modern Age has allowed establishing the following. (1) The idea of philosophy, formulated by Plato, has hold sway in modern history. It corresponds to the demands of a new reality, which is revealed as a process. (2) In the context of a new reality, the idea of philosophy revealed previously unknown qualities. Martin Heidegger proved that the idea of philosophy does not need Mediators or any other external source. Instead, the unity of certain discourse and way of life has an inner source, which Heidegger coined the term "the appropriated clearing" (die ereignete Lichtung). This source reveals in the idea of philosophy the potency ( $\delta u^{\prime} v \breve{\alpha} \mu \breve{\iota}$, dúnamis), which under certain conditions is capable of transforming an individual discourse and a way of life independently.
\end{abstract}

Keywords: philosophy, Modern Age, being in itself, Martin Heidegger, meaningful presence.

Introduction

The replacement of the geocentric world picture with Vernadsky's model "Evolving Substance" led to the formation of a new philosophy of knowledge with its research methodology (Bazaluk \& Kharchenko, 2018). The Earth lost its place as the "centre" of the Universe and became an ordinary planet in the expanding Universe. Man discovered that Gods (God) had not created the world. It had constantly been changing and complicating according to the laws of physics, chemistry, biology, etc. The Universe, the biosphere, the noosphere - everything changed in a whole and in parts. For the last four centuries, epistemology is in the constant search, understanding and evaluation of new significative meanings of Being. Among the key thinkers of the second stage, we want to note René Descartes, Immanuel Kant, Georg Wilhelm Hegel and Martin Heidegger. The key phrase of the epistemology of this period is the phrase of Friedrich Nietzsche: "God is dead!" Nietzsche wrote about it very impressively and emotionally in the book "The Gay Science": "Have you not heard of that madman who lit a lantern in the bright morning hours, ran to the marketplace, and cried incessantly: "I seek God! I seek God!” ... "Whither is God?" he cried; "I will tell you. We have killed him - you and I. All of us are his murderers. ...Do we hear nothing as yet of the noise of the gravediggers who are burying God? Do we smell nothing as yet of the divine decomposition? Gods, too, decompose. God is dead. God remains dead. And we have killed him" (Nietzsche, 1990, p. 592).

Nietzsche's categorical statement "God is dead!" drew a line under the history of world culture in his own way (Heidegger, 2006). Humanity needed new fundamental markers of their identification in an expanding universe (Stelmakh \& Kotova, 2020). The image of Plato's philosophy, which had been determining the basis of world knowledge, the meaning of human life and the cultural ideal for four millennia, was replaced by a new philosophy, in which there was no place for the static cosmos, the Supreme Deity, the necessity to serve Him and believe in Him (Kieliszek, 2020; Krichevsky, 2020). 
The philosophy of the Modern Age is built on certain sets of new fundamental meanings of Being, each of which has its history. We would like to highlight the following:

1. The world around us is the Universe, the biosphere, and the noosphere of the Earth, which evolve.

2. The Universe, biological life and man have resulted from natural physicochemical processes, some of which have been scientifically established and proven.

3. Biological organisms and humans originated on the Earth as a result of abiogenesis or panspermia.

4. Modern man is a Homo sapiens. He has emerged from primates as a result of neuroevolution. Its main difference from other anthropoid apes is in the structure and functions of the brain.

5. A man carries out activities that can be compared with the geological chronicle of the Earth. World history is a continuously and nonlinearly change in the structure and appearance of the planet Earth.

Epistemology has established qualitatively new markers of human identity. Man has begun to identify himself with a planetary force that is capable, in conditions of uncompromising competition with geological and biological processes, to create a sphere of his existence on the Earth - the noosphere. Or, as Moisey Rubinstein (2008) summed up in one phrase, the entire essence of the book "The Vocation of Man" (in German: Die Bestimmung des Menschen) by Johann Gottlieb Fichte: "the ultimate goal of man, in respect of himself and others, as well as in respect of the world and nature, is the accession of reason and the endless imposition and expansion of his power" (p. 126). The philosophy of the Modern Age freed man's worldview from dependence: "Creator - Mediator - Executor". The man realized himself as an important participant in the process of transforming the Earth.
The Philosophy of the Modern Age:

The Return of Lost Meanings

Over the past 400 years of modern history, professors of philosophy have been able to understand and accept the fact of the worldview change. The question of being was not as obvious to them as to Plato, Aristotle, and other predecessors. New facts did not allow perceiving being as the kalos cosmos, created by God, once and forever (Timaeus, 28a-34b). "Being" had been changing. It was necessary to reconsider the genesis of being and answer a question, "What is the world as a process?"

At the beginning of the $19^{\text {th }}$ century, two fundamental studies were published - "Science of Logic" (between 1812 and 1816) and "Encyclopaedia of the Philosophical Sciences" (1817) by Georg Wilhelm Friedrich Hegel. Hegel reconsidered being as a process and introduced new terminology to define disclosed events. Hegel (2010) regarded being as "the concept only as it is in itself" and "a process of passing over into another" (p. 135). As the other, Hegel considered nothing. "The truth of being as well as of nothing is, therefore, the unity of both" (Hegel, 2010, p. 140). The unity of being and nothing represented the becoming, as well as the beginning, which was also becoming, but it already expresses the relation to the further progression (Hegel, 2010, p. 142).

It is not hard to notice that Hegel, who was strong in Greek, rethought the kalos cosmos in new terminology. The unity of being and nothing corresponded to the kalos cosmos, the becoming to gígnomai ( $\gamma^{\prime} \gamma v o \mu \alpha$ ), and the beginning to genesis ( $\gamma \varepsilon ́ v \varepsilon \sigma ı v)$ (Liddell \& Scott, 1940).

In search of an answer to "What is being?" Hegel (2010) concluded that the becoming was the true expression of "not only the unity of being and nothing but the unrest in itself" (p. 143). It was the unrest of the unity of being and nothing that represented unity not merely immobile but as a process. Hegel specified the manifesta- 
tion of this process with the term Dasein. Dasein is a "one-sided and finite" form of unity of being and nothing, in which the contradictions in their relationship temporarily disappeared. Dasein is a unity in which being and nothing are only moments (Hegel, 2010, p. 143).

Hegel's studies were important, but not the only, in the search for answers to the question of the essence of being. Professors of philosophy achieved significant results in understanding the world as a process and in creating new methods and tools for its research. We would like to highlight the following among the achieved results:

1. The dispute between rationalists and empiricists of the $16^{\text {th }}$ century. The dispute continues to the present. It concerns the fundamental nature of reality, including the existence of God, the nature of truth, the place of man on the scale of the Earth and the Universe, the relationship between the mind and body, and so on (Markie, 2017). The understanding of being as the source of our ideas and the nature of causal connections in the world was extended due to the dispute.

2. Kant's "Copernican revolution" (the end of the $18^{\text {th }}$ century). In "Critique of Pure Reason," Kant proved that authentic knowledge of the essence of things does not exist. The understanding depends on the nature of cognitive abilities. Therefore, a person can perceive the world only in an image in which the world "appears specifically to him/her," and not in that state in which "he/she is by himself/herself". Kant formulated it as follows: "we can cognize of things a priori only what we ourselves have put into them." Therefore, defining ideas such as God, truth, peace, faith and others cannot be considered as authentic or inauthentic. They cannot be confirmed by empirical methods. They exist as "things in themselves" and cannot be understood (Kant, 1964).

3. The philosophical discourse was liberated of orthodoxy. The non-philosophical functions, such as pre-Christian and Christian exegesis, tendentiousness of thinking, compartmentalization of consciousness, niche discipline, etc., were rejected (Hadot, 2005). Instead, philosophers focused on studying the world, revealing itself as a process, and creating the "ideal" models of global sustainability and prosperity regarding new knowledge.

4. Throughout modern history, various philosophical movements such as "liberalism," "Marxism," "psychoanalysis," "existentialism," etc., were formed on the basis of the theories and the "ideal" model of sustainable development. These movements covered different population groups who lived in the territories of all continents. The main feature of new theories and "ideal" models was an effort to reach a consensus between the need to transform discourse and a way of life of citizens on the achievement of the proclaimed ideal on the one hand, and their rights, freedoms and interests, on the other hand. The search for an effective combination of the possibilities of monarchy and democracy to establish an "ideal" world order was carried out through the created political and educational theories.

5. There was developed a process approach in the theoretical understanding of the world and the practical development of the achieved results. A process view of reality involved the development of a new metaphysical and metaphilosophical paradigm with its methodology and tools. There was formed process philosophy that, unlike traditional metaphysics, did not focus on the eternalist being and on what there is. Process philosophy analyses ways of occurring, i.e., what is occurring. It studies the regular behaviour of dynamic systems in the process of their continuous and nonlinear complication (Seibt, 2020).

Over the past 400 years of the modern period, professors of philosophy managed to revive philosophy as:

1. a discourse that combines common human sense and new ideas about the world as a pro- 
cess;

2. a practice that transforms every new theory and the "ideal" model of global sustainable development into the method of society conversion at the national, regional and global levels.

In modern history, the term "philosophy" returned its meanings, lost in the Middle Ages. Philosophy again was started to be seen as the specific discourse and way of life, whereas "theology" turned into a narrow academic discipline limited by religious epistemology.

\section{The Philosophy of Martin Heidegger}

Currently, the philosophy of Martin Heidegger most fully represents the epistemology "Those who transform the Earth". Heidegger not only constantly appeals to the ideas of Plato, Aristotle and other classics of Ancient Greece, but also relies on insights and generalisations of the philosophers of the Modern Age: Immanuel Kant, Georg Wilhelm Hegel, Wilhelm Dilthey, Edmund Husserl and others (Sheehan, 2014; Okorokov, 2018). In a letter to Karl Jaspers, Heidegger characterized himself as "the museum attendant, who draws the curtains aside so that the great works of philosophy should be seen more clearly" (Safranski, 2005, p. 565). All these allowed Heidegger, on the one hand, to focus on the search of the source ( $\gamma \varepsilon$ veбıv) of being, which enabled being to manifest itself as "being itself" or "being as such," and, on the other hand, to advance further than others in creating new methods and tools for the research of the being source or the world as a process. Heidegger created new value judgments based on the idea of philosophy. He revealed and approved the understanding of the idea of philosophy in an evolving world.

The following discoveries, made by Heidegger, are important for our research. First, Heidegger specified that the question of "the essence of being" implied the fact of the "being in itself" or any other "meaningful presence". At all times, this question was the first priority for the philosophical school. The transcendental ideal was formulated on the basis of Aletheia of the Kalos cosmos.

However, why is the question "What is the source of such a meaningful presence?" not of the high priority for philosophy? Heidegger (1997) came to a conclusion that starting with Plato, the issue of the source to come into being, or gígnomai ( $\gamma$ í $\gamma v \mu \mu \alpha)$, was forgotten, as a matter of fact, the fact of the neglect was soon forgotten as well.

Heidegger was partially right. Let us pay attention to the following fact. Actually, the question of the genesis of agathos and demiurge, created the kalos cosmos (Timaeus, 29a) (= the genesis of the Supreme Deity, created the divine order) was not raised in educational theories of the philosophical school. In ancient Greece and the Middle Ages, the idea of agathos, which determines the actions of the demiurge, represented the highest idea, ideal and values (Jaeger, 1947). All the defining terms of modern philosophy and their derivatives were of secondary importance in relation to the demiurge, who was agathos. Being

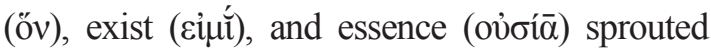
from the idea of agathos ( $\dot{\alpha} \gamma \alpha \theta$ oṽ i $\delta \varepsilon \dot{\varepsilon} \alpha v)$ (Republic, 6.508e). The idea of agathos was the defining axiom on the basis of which all philosophical reflection took place. The idea of agathos generated eternal and perfect ideals of moral purity, manifested in irreproachable conduct in every philosophical theory and "ideal model" of sustainable development. It was always and everywhere invisibly present in the studies of the philosophical school and transformed them into practice (Jaeger, 1986).

In modern philosophy, the idea of agathos was not studied. Its significance and the richness of the meanings were lost in the Middle Ages when translating into other languages and due to the replacement with other terms. Some meanings of the agathos were switched to ethics and esthetics, which formed axiology in the $19^{\text {th }}$ century. The philosophical school has lost the most 
important relationship between the processes that took place in the cosmos (the Universe) and in society. The social system was not longer regarded as a mirror image of the kalos cosmos, in which agathos manifested itself. Therefore, when Heidegger raised the question of the source of being, nominally, he implied the study of the gígnomai agathos as "the essence of being." However, he investigated the process of the birth of derivatives of the agathos essences, following the rest of the German philosophy representtatives. He repeated the way followed by Aristotle. Still, Aristotle, as any scholar of that time, considered the idea of agathos an unshakable axiom, and its study was out of the question. Aristotle

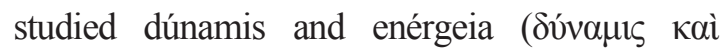
$\dot{\varepsilon} v \varepsilon \dot{\varepsilon} \rho \varepsilon 1 \alpha$ ) as the derivatives of the agathos. While Heidegger was convinced that through learning the source of Dasein, he was exploring the fundamental principle of the world as a process (Gonzalez, 2019).

In any case, Heidegger was right to state that acknowledging the fact of the genesis, on the one hand, and exploring the driving force of gígnomai ( $\gamma$ i $\gamma \gamma$ oul), on the other hand, are different research subjects. Acknowledging the fact of the genesis of the idea of agathos admits of the "ideal models" construction both of static and evolving cosmos. Exploring of the gígnomai agathos is an exploring of the process of genesis (= genesis as such, = genesis in itself, = genesis itself), i.e., constructing exclusively evolving "ideal" models of cosmos. Heidegger investigated this issue in his book "Being and Time" ("Sein und Zeit") (Heidegger, 1997).

Heidegger tried to prove that exploring the genesis process should be the first and foremost. The obtained results allowed us to understand what provides the "realness" of things and in such a way that realness might be read. Heidegger called the result of the exploring of the genesis as such "the appropriated clearing" (die ereignete Lichtung). Thomas Sheehan (Sheehan, 2014) proved that Heidegger's major topic was not being, but the clearing (der Lichtung), in which things could manifest themselves and in this sense "be".

Let us clarify. There are two reasons why Heidegger's terminology is complex, and at first glance, contradictory. First, Heidegger reconsidered Greek terminology and its meanings in the language space of the German language. Heidegger, like Hegel, knew Greek and studied the works of the scholarchs in the original. However, Hegel confined to the reconsidering of the ideas of heavyweight scholarchs with the standard terminology, while Heidegger tried to convey the meanings of Greek terms maximally accurate, using the potential of the German language. Hereof it follows the second reason: Heidegger experimented with the German language. He improved not only the Greek meanings but also the language of the transmission of the improved meanings itself. Heidegger selected German words for Greek terms, and if necessary, he changed these words or created new ones, achieving the maximum possible closeness of the semantic charge (Heidegger, 1986; Sheehan, 2014). Heidegger created new terminology to convey the results of the study of genesis as such. For example, "the appropriated clearing" (die ereignete Lichtung) is nothing more than the disclosedness of the gígnomai (= openness of the genesis process). Before Heidegger decided on the term "der Lichtung," he used the terms "Wahrheit," "Entbergung," "Entborgenheit," "Unverborgenheit," “Unverdecktsein," etc. (Sheehan, 2014). It would be wrong to say that "der Lichtung" was Heidegger's final choice. The meanings of "der Lichtung" are based on the history of the development of the meaning in the previous terms. In-depth language training could be explained in this case by Heidegger's striving for the identity of German words with the Greek term $\alpha \dot{\alpha}-\lambda \eta \theta \dot{\eta} s$ (a-lēthếs), in which the obvious opposition was transmitted: disclosed-

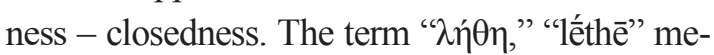
ant oblivion in Greek (Liddell \& Scott, 1940). Therefore, revealing the genesis as such, Heidegger aimed at conveying the meanings of the tran- 
sition of being (= thing) from a state of closeness, oblivion $(\lambda \eta \dot{\theta} \theta)$ into a state of openness ( $\dot{\alpha}-$ $\lambda \eta \theta \dot{\prime} s)$ or Sein as Anwesen, "meaningful presence".

Heidegger's second important discovery was the change of the focus on the study of philosophy. The priority of the genesis issue as such made the studies of the causes of the intelligibility of things urgent and over-relevant. The subject of Heidegger's study was that which gave the significance and meaningful presence, or Sein as Anwesen (Sein as Anwesen). For Heidegger, the openness of being was obvious, so he used the term Dasein instead of Sein. Da is the openness of Sein, "being as such," its temporality. Dasein is a process, a passage, in which time was a key issue.

The exploring of Dasein as the openness of being as such allowed Heidegger to highlight and systematize the external manifestations of being (kalos). It gave him an understanding of the essence of being or the process of its birth. Heidegger specified that process as die Herkunft von Anwesen, or the source and the origin of meaningful presence (Sheehan, 2014). Heidegger defined that Dasein is not only just the open presence of being. It is a specifically meaningful presence of things to humans. In Heidegger's opinion, the end result of the genesis research as such should be a search therein for everything that will "be responsible for the fact that things can and must be discursively intelligible (= must "have being") if we are to encounter them at all". For Heidegger, the end result of the search was "the ever-operative yet intrinsically hidden thrown-openness that is the appropriated clearing" (Sheehan, 2014, pp. xviii-xix).

Third, the key importance of time in understanding Dasein changed the purpose of raising the question of the source of Dasein. According to Heidegger, the question should not be asked to be answered, or, more precisely, not so much for that. The importance of the question was to maintain and strengthen the degree of actualization of the question itself. The immortality of Sophia, the Supreme Deity, Being, Dasein, and finally, the very idea of agathos is not in the answers that they "existence." Their immortality provides a turning towards oneself and an eternal return to oneself - to the genesis as such. Therefore, just like the philosophers of Ancient Greece, Heidegger did not write "doctrines" and "theories." His legacy consists of lecture notes and articles that move, or rather, eternally return to knowing the source of Dasein (= the source of the birth of being) for its all-encompassing intelligibility as a thing. This move back to the origin ( $\gamma \varepsilon \dot{v \varepsilon \sigma\lrcorner v)}$ Heidegger called "the return from meaningful presence to appropriation," where "there is no more room even for the word "being" (Sheehan, 2014, p. 19).

Heidegger understood the return to appropriation not as moving along one path to the final goal and for the sake of getting the desired answer. This return was filled with Aristotelian reasoning. The image of philosophy proposed by Aristotle had the edge for Heidegger, as well as Hegel. It allowed Heidegger to provide philosophy as a disinterested pursuit of the source of being for his own philosophy sake. In that eternal return to the original (genesis), there was an increase in the scale and scope of interrogation, through which individual intelligibility of the essence of things was accomplished. Therefore, philosophy turned into a kinetic structure of transcendence and return and provided personal clarification (Sheehan, 2014).

Heidegger has established philosophy as the only possible platform for interdisciplinary methodology and tools designed to study the individual intelligibility of the source of Dasein. Heidegger's scientific image of philosophy is the possibility of clearing, or rather of the appropriated (that is, singled out for a specific purpose) clearing (die ereignete Lichtung) of individual being.

Fourth, we find the direct influence of Aristotle's philosophy in Heidegger's answer to the question about the source of Dasein (Gonzalez, 2019; Sheehan, 2014). According to Aristotle, 
the kalos cosmos manifested one more "meaningful presence." Along with agathos, dunamis

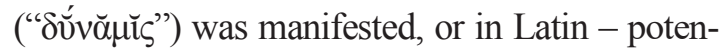
cy. Thereafter, exegetes ascribed potency to the logos. Due to its potency, the logos possessed

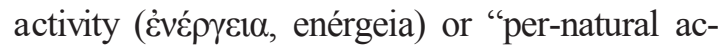
tion" (= cosmic force). Hence, the main definition of the "logos" was "the movement from a lower order to the highest one in the static body of the cosmos" (Heidegger, 2018).

Heidegger used the Aristotelian method to explore the essence of gígnomai in the study of the process of genesis. He specified the obtained result with the term "the clearing" (der Lichtung). To get the meaning of the term "the clearing," it is important to understand the meanings that Heidegger put into the term Dasein (Koyré, 1999). On this issue, we rely on the authority of Thomas Sheehan (2014), who proved that the Da in Dasein, just like ex in existence, implied an openness or clearing of a human being for Heidegger. This fact was so obvious for Heidegger that he explored the second part of the words: sein and sistence. He was interested in the question: How does a thing's meaningful-presence-as come about in openness? Heidegger was interested in the movement of Sein in Da, or in the Aristotelian terminology - enérgeia into dúnamis. Heidegger positioned the availability of this study as the openness of the birth of being for rational research. The meaning of the clearing became visible through the availability.

Heidegger specified that the meaning of the clearing is the fact that Dasein structurally transcends things and returns to them. Dasein is "what existentially holds open the clearing and makes possible the particular meanings (Bedeutungen) of things" (Sheehan, 2014, p. 26). In a manuscript devoted to Aristotle, Heidegger gives a laconic definition of his philosophical intention: "The subject of the philosophical question is human existence, the question being about the character of its Being" (Safranski, 2005, p. 175). However, the anthropological interpretation of Heidegger's teachings appears to be a mistake.
Alexandre Koyré (1999) clarified: "Dasein is a "structure" or, if a more familiar term is used, an essence that is actualized in a man, but which could (and perhaps it does) become actualized in other "entities," or even not actualized at all". Generally speaking, the movement of Dasein or the clearing is a kinetic structure of transcendence and return. In fact, these are the revived meanings of the logos ( $\lambda$ ó $\gamma \circ$ s), given in new terms.

\section{Conclusion}

Summarizing all the above, it should be pointed out that in the image of philosophy proposed by Heidegger, the idea of philosophy turned out to be significant in itself. Before Heidegger, the understanding of the idea of philosophy did not go beyond the formal boundaries of the term "idea". It was considered as the unchanging mental archetype that was promoted in world history by the representatives of the philosophical school. The idea of philosophy a priori needed the Mediators or an external force that revived, promoted and transformed it into the specific discourse and way of life. For example, Plato suggested the philosophers as the Mediators, and Augustine suggested the prophets and the Holy Apostles. The image of philosophy proposed by Heidegger eliminated the dependence of the idea of philosophy on the Mediators and any other external sources. It turned out that enérgeia, as an internal source that provides clearing in being, is immanent in the idea of philosophy. All the arising diversity of the "ideal model" of sustainable development is neither more nor less than clearing or real manifestation of the source of Dasein through the potency of the idea of philosophy. By the revealed meanings of "the appropriated clearing" (die ereignete Lichtung), the idea of philosophy was introduced as "the way, the truth, and the life". It proved to be the only possible basis, which in a new understanding of reality was able to transform a variety of the interdisciplinary approaches and knowledge 
achieved from information on the world as a process into the specific discourse and way of human life.

In Heidegger's philosophy, Nietzsche's phrase "God is dead!" was a borderline that separated the preceding epistemology from new meanings of Being. In his works, Heidegger repeatedly emphasized the difference between the "old" and "new" worldviews. For example, in the "Letter on Humanism," polemicizing with rationalism and its derived forms: humanism and metaphysics, Heidegger further clarifies the previous understanding of humanism. In the concept of "humanism," the Romans laid the main markers of human identity, on the basis of which later the sophists' educational practices were built. Therefore, by laying new fundamental meanings in the concept of "humanism," Heidegger further exacerbated the difference between the "old" and "new" worldviews, as well as between the "static" and "process" methods of exploring the world.

Heidegger's understanding of humanism is important for our research by the fact that it focuses on the meanings of three key markers of human identity: epistemology, the meaning of human life and the cultural ideal. "Humanism" now means, in case we decide to retain the word, that the essence of the human being is essential for the truth of being, specifically in such a way that what matters is not the human being simply as such" (Heidegger, 1949, p. 263). In this definition of humanism, on the one hand, Heidegger emphasizes the self-sufficiency of human beings and the understanding of man as a powerful transforming planetary force. It follows that the epistemology of "Those who transform the Earth" reveals a human as an important actor in planetary evolution. However, on the other hand, in the definition of humanism, Heidegger emphasises that the transforming power of man has borderlines that are not dependent on the being of man. The point at issue is the inclusion of the planetary evolution into the evolution of the Universe and human place and role in the process.

\section{References}

Bazaluk, O., \& Kharchenko, L. (2018). The philosophy of the cosmos as the new universal philosophical teaching about being. Philosophy and Cosmology, 21, 613. doi:10.29202/phil-cosm/21/1

Gonzalez, F. J. (2019). Movement versus activity: Heidegger's 1922/23 seminar on Aristotle's ontology of life. British Journal for the History of Philosophy, 27(3), 615-634. doi:10.1163/1569164012341404

Hadot, P. (2005). Filosofiya kak sposob zhit': Besedy s Zhanni Karliye i Arnol'dom I. Devidsonom (Philosophy as a way of life: conversations with Jeannie Carlier and Arnold I. Davidson, in Russian). Moscow, Saint Petersburg: Stepnoy veter.

Hegel, G. W. F. (2010). In M. Baur (Ed.), Encyclopedia of the philosophical sciences in basic outline. Cambridge University Press. Retrieved from https://academiaanalitica.files.wordpress.com/2016/10/georg-wilhelm-friedrich-hegel-encyclopaedia-of-the-philosophical-sciencesin-basic-outline_-part.pdf

Heidegger, M. (1949). Letter on "Humanism". (F. A. Capuzzi, Trans.). Retrieved from https://warwick.ac.uk/fac/arts/english/c urrentstudents/undergraduate/modules/en354/syllabus/seminars/letteronhuman ism1949.pdf

Heidegger, M. (1986). Ucheniye Platona ob istine (Plato's doctrine of truth, in Russian) (T. Vasilyeva, Trans.). In Istorikofilosofskii yezhegodnik (Historical and Philosophical Yearbook) (pp. 255-275). Moscow: Nauka.

Heidegger, M. (1997). Bytiye i vremya (Being and time, in Russian). Moscow: Ad Marginem. 
Heidegger, M. (2006). Nitsshe i pustota (Nietzsche and emptiness, in Russian). Moscow: Eksmo.

Heidegger, M. (2018). Heraclitus: The inception of occidental thinking; and logic: Heraclitus's doctrine of the logos. (J. G. Assaiante \& S. M. Ewegen, Trans.). Bloomsbury.

Jaeger, W. (1947). Paideia: The ideals of Greek culture: Volume II: In search of the divine centre. Oxford: Basil Blackwell. Retrieved from https://archive.org/stream/werner-jaeger-paideia-the-ideals-ofgreek-culture-vol2\#page/n1/mode/2up

Jaeger, W. (1986). Paideia: The ideals of Greek culture: Volume III: The conflict of cultural ideals in the age of Plato. Oxford: Oxford University Press.

Kant, I. (1964). Sochineniya v shesti tomakh (Works in six volumes, in Russian). Moscow: Mysl.

Kieliszek, Z. (2020). Human education towards goodness. The potential of the Kantian concept of "perpetual peace" in shaping future peaceful relations among nations. Philosophy and Cosmology, 24, 151-158. doi:10.29202/phil-cosm/24/15

Koyré, A. (1999). Filosofskaya evolyutsiya Martina Khaydeggera (Martin Heidegger's philosophical evolution, in Russian). Logos, 10, 113-136. Retrieved from http://www.ruthenia.ru/logos/number/1999_10/06.htm\#_ftn1

Krichevsky, S. (2020). Creation of a "cosmic" human: Ideas, technologies, projects, experience, risks, limitations, and prospects. Future Human Image, 13, 3245. doi:10.29202/fhi/13/4

Liddell, H.G. \& Scott, R. (1940). A Greek-English lexicon. Oxford: Clarendon Press.

Markie, P. (2017). Rationalism vs. empiricism. In E. N. Zalta (Ed.), The Stanford encyclopedia of philosophy. Retrieved from https://plato.stanford.edu/entries/rationa lism-empiricism/

Nietzsche, Fr. (1990). Sochineniya v dvukh tomakh (Works in two volumes, in Russian). Moscow: Mysl.

Okorokov, V. (2018). Limits of thought in the light of nature and divinity. A return to ancient thought or the quest for the being of primordial thinking in the later Heidegger. Philosophy and Cosmology, 20, 170-184. doi:10.29202/phil-cosm/$20 / 17$

Plato (2020). Republic. Retrieved from http://www.perseus.tufts.edu/hopper/searchre sults?q=Republic

Plato (2020). Timaeus. Retrieved from http://www.perseus.tufts.edu/hopper/searchre sults? $\mathrm{q}=$ Timaeus

Rubinstein, M. (2008). O smysle zhizni. Trudy po filosofii tsennosti, teorii obrazovaniya $\mathrm{i}$ universitetskomu voprosu (On the meaning of life. Works on the philosophy of value, theory of education and university issue, in Russian). Moscow: Territory Budushchego.

Safranski, R. (2005). Khaydegger: germanskiy master i ego vremya (Heidegger: A master from Germany and his time, in Russian) (T. Baskakova, Trans.). Moscow: Molodaya Gvardiya.

Seibt, J. (2020). Process philosophy. In E. N. Zalta (Ed.), The Stanford encyclopedia of philosophy. Retrieved from https://plato.stanford.edu/archives/sum2020/entries/process-philosophy

Sheehan, T. (2014). Making sense of Heidegger: A paradigm shift. Rowman \& Littlefield International.

Stelmakh, S., \& Kotova, S. (2020). Concept of an "ideal Europe" in the philosophical discourse during World War I (19141918): British rationalism versus German "individualism". Future Human Image, 13, 94-101. https://doi.org/10.29202/fhi/13/10 